Michał Gregorczyk *

ORCID: 0000-0003-4572-4312

Uniwersytet Jagielloński

DOI: $10.19195 / 1733-5779.25 .1$

\title{
Brak rejestracji znaku towarowego - o sposobach ochrony nierejestrowanych znaków towarowych przed naruszeniami na gruncie prawa polskiego
}

JEL Classification: K210, K200

Słowa kluczowe: znak towarowy, niezarejestrowany znak towarowy, oznaczenia

Keywords: trademark, unregistered trademark, designations

\begin{abstract}
Abstrakt: Celem artykułu jest przybliżenie problematyki nierejestrowanych znaków towarowych. Autor dokonuje analizy istniejących regulacji z zakresu prawa krajowego wraz ze wskazaniem źródeł prawa unijnego. Rozważona zostaje możliwość stosowania ich w odniesieniu do nierejestrowanych znaków towarowych, dla których obecnie brakuje definicji legalnych. Postawiono hipotezę o konieczności uznania istnienia odrębnego dobra prawnego w postaci prawa do nierejestrowanego znaku towarowego powstałego na podstawie możliwości ochrony niezarejestrowanych znaków towarowych na podstawie innych niż prawo ochronne na znak towarowy zarejestrowany. Rozważono uzyskanie ochrony na nierejestrowany znak towarowy w ujęciu prawa o zwalczaniu nieuczciwej konkurencji w postaci ochrony jako oznaczenia przedsiębiorcy lub oznaczenia przedsiębiorstwa, a także wzajemne relacje między ochroną na podstawie prawa własności przemysłowej a przepisami o zwalczaniu nieuczciwej konkurencji. Dokonano porównania istniejących regulacji oraz orzecznictwa, a następnie wyciągnięto wnioski odnośnie do możliwości ich zastosowania w specyficznej sytuacji niezarejestrowanego znaku towarowego. Artykuł kończy podsumowanie dotychczasowych rozważań, w tym w szczególności konieczność wyróżnienia odrębnego prawa do znaku zarejestrowanego i uznanie jego funkcjonowania w obrocie.
\end{abstract}

\section{Without trademark registration - on how to protect unregistered trademarks from violations under Polish law}

Abstract: The article aims to familiarize with the issue of unregistered trademarks. The author analyzes existing regulations in the field of national law along with an indication of the sources of EU law. The possibilities of applying them to unregistered trademarks are considered, for which

* Opiekun naukowy (Scientific Tutor) - Paweł Podrecki 
there are currently no legal definitions. The author hypothesizes the need to recognize the existence of a separate legal right in the form of a right to an unregistered trademark created on the basis of the possibility of protecting unregistered trademarks on the basis of other than protection rights on a registered trademark. Consideration is given to obtaining protection for an unregistered trademark in terms of the law on combating unfair competition in the form of protection as an entrepreneur's designation or business designation, as well as mutual relations between industrial property rights and anti-unfair competition regulations. The author compares existing regulations and caselaw and then draws conclusions regarding the possibility of their application in the specific situation of an unregistered trademark. The article ends with a summary and conclusions in which the author summarized the previous considerations, in particular the necessity to distinguish a separate right to the registered mark and recognition of its functioning on the market.

Kluczowym elementem rozpoznawalności przedsiębiorstwa jest stosowane przez niego oznaczenie pozwalające na określenie, który z produktów dostępnych na rynku został wyprodukowany i jest oferowany przez konkretne przedsiębiorstwo. To jedna z podstaw skutecznego marketingu, więc używane oznaczenia nabierają realnej wartości majątkowej niezależnie od ich prawnego statusu. Skojarzenie przez konsumentów określonych symboli jako należących do konkretnego uczestnika rynku jest też jedną z głównych motywacji ich wyborów konsumenckich. Nie wszystkie z takich oznaczeń mogą jednak uzyskać ochronę wynikającą ze zgłoszenia do rejestracji we właściwych urzędach. Brak tej ochrony może wynikać z rozmaitych przyczyn, między innymi z niewystarczającej zdolności odróżniającej, która nie została jeszcze osiągnięta nawet w wyniku rzeczywistego używania zgłoszonego znaku, niechęć do ponoszenia kosztów postępowania rejestrowego lub nieznajomość reguł ochrony oznaczeń. Wbrew panującemu przekonaniu o dołożeniu przez przedsiębiorców najwyższych starań w kwestii ochrony swojego przedsięwzięcia przypadki takie nie należą do rzadkości. Jednocześnie wielokrotnie zachodzi konieczność ochrony swojej pozycji rynkowej przed działaniami konkurentów, w tym przede wszystkim obrony praw do wypracowanej marki i rozpoznawalności. Nieistnienie prawa ochronnego obejmującego możliwość wyłączenia innych podmiotów z posługiwania się znakiem zmusza użytkowników niezgłoszonych oznaczeń do poszukiwania ochrony w analogii oraz alternatywnych dla prawa własności przemysłowej systemach ochrony praw niematerialnych.

Sytuację dysponentów niezarejestrowanych znaków towarowych komplikuje brak legalnej definicji niezarejestrowanego znaku towarowego. Również w ustawie Prawo własności przemysłowej ${ }^{1}$ nie przewidziano wprost żadnej bezpośredniej drogi ochrony takich oznaczeń. Nie oznacza to jednak, że w wypadku naruszenia takiego znaku przez inne podmioty jego użytkownik jest bezradny. $\mathrm{W}$ artykule dokonana zostanie analiza pojęcia i charakteru niezarejestrowanych

1 Ustawa z dnia 30 czerwca 2000 roku Prawo własności przemysłowej, Dz.U. z 2001 r. Nr 49, poz. 508, dalej: Prawo własności przemysłowej. 
znaków towarowych, zaistniałych problemów oraz istniejących metod ich rozwiązania. Wskazane zostaną też konieczne działania, jakie powinny być podjęte przez legislatora celem rozwiązania powstałych problemów.

\section{Pojęcie nierejestrowanego znaku towarowego}

W polskim prawie źródła ochrony znaków towarowych upatrywane są w dwóch ustawach: Prawie własności przemysłowej oraz ustawie o zwalczaniu nieuczciwej konkurencji ${ }^{2}$. Z powodu członkostwa w Unii Europejskiej w państwie polskim zastosowanie znajdą też akty prawa unijnego regulujące tę materię. Obejmują one porozumienie TRIPS ${ }^{3}$ (stanowiące nie tylko część prawa unijnego, lecz także ogólnomiędzynarodowego), rozporządzenie Parlamentu Europejskiego i Rady (UE) 2017/1001 z dnia 14 czerwca 2017 roku w sprawie znaku towarowego Unii Europejskiej ${ }^{4}$ oraz orzecznictwo TSUE. Pomocniczo do ustalenia nieuregulowanych kwestii można w rozważaniach naukowych odwoływać się do pozostałych systemów prawnych. Przepisy prawa unijnego harmonizują jednak głównie ochronę znaków towarowych zarejestrowanych. Znaki towarowe niezarejestrowane dotychczas jedynie częściowo uzyskiwały ochronę w niektórych państwach członkowskich w wyniku ich rzeczywistego używania ${ }^{5}$. Jednak wspomniane rozporządzenie Parlamentu Europejskiego i Rady (UE) 2017/1001 z dnia 14 czerwca 2017 roku w art. 8 wprowadziło względną przeszkodę rejestracji w postaci sprzeciwu właściciela niezarejestrowanego znaku towarowego lub podobnego oznaczenia. Jest to efektem dostrzeżenia występującego problemu oraz chęci jego rozwiązania.

Ze względu na brak legalnej definicji konieczne jest ustalenie, które ze znaków używanych do oznaczania towarów zasługują na pojęcie nierejestrowanego znaku towarowego. Pomocna w określeniu, co należy rozumieć przez niezarejestrowany znak towarowy, będzie definicja zawarta $\mathrm{w}$ art. 120 Prawa własności przemysłowej: „Znakiem towarowym może być każde oznaczenie, które można przedstawić w sposób graficzny, jeżeli oznaczenie takie nadaje się do odróżnienia towarów jednego przedsiębiorstwa od towarów innego przedsiębiorstwa". Podobnie jak w przypadku znaków zarejestrowanych należy uznać, że niezarejestrowanym znakiem towarowym mogą być wszystkie oznaczenia pozwalające na odróżnienie

2 Ustawa z dnia 16 kwietnia 1993 roku o zwalczaniu nieuczciwej konkurencji, Dz.U. z 1993 r. $\mathrm{Nr} 47$, poz. 211, dalej: ustawa o zwalczaniu nieuczciwej konkurencji. Zob. M. Kondrat, Ochrona znaków towarowych przed naruszeniami w internecie, Warszawa 2008, LEX 81492, rozdz. 1.

3 Porozumienie w Sprawie Handlowych Aspektów Praw Własności Intelektualnej zawarte w ramach Światowej Organizacji Handlu, w której Unia Europejska występuje jako jednolity podmiot reprezentowany przez Komisje.

4 Rozporządzenie Parlamentu Europejskiego i Rady (UE) 2017/1001 z dnia 14 czerwca 2017 roku w sprawie znaku towarowego Unii Europejskiej (Dz.U.UE.L.2017.154.1).

5 M. Kondrat, op. cit. 
pochodzenia towarów konkretnego przedsiębiorcy od towarów innego podmiotu. Do powstania takiego znaku konieczny jest sam fakt wykorzystywania oznaczenia w obrocie ${ }^{6}$.

Spośród funkcji pełnionych przez znak towarowy należy wskazać: funkcję oznaczenia pochodzenia, funkcję jakościową, funkcję reklamową ${ }^{7}$. Funkcja pochodzenia jest podstawową cechą przysługującą znakowi towarowemu - przez zapewnienie, że dany produkt pochodzi z konkretnego źródła. Uzupełniają ją zadania jakościowe oraz reklamowe znaków. Pierwsze z nich zakłada skojarzenie znaku z pewnymi charakterystycznymi cechami. Tak jak funkcja pochodzenia zapewnia o szczególnej jakości i właściwościach, jakimi powinny się cechować towary i usługi nim oznaczone. Powiązane $\mathrm{z}$ tą cechą są funkcje reklamowe, lokujące $\mathrm{w}$ świadomości konsumentów informacje o istnieniu danego znaku oraz powiązanych z nim cech. Wiąże się to z zagadnieniem znaków renomowanych oraz powszechnie znanych, omówionych w dalszej części artykułu.

W praktyce należy uznać, że definicja znaku towarowego zawarta w Prawie własności przemysłowej w pełni może być wykorzystywana przy opisie znaków towarowych niepodlegających ochronie w trybie przewidzianym tą ustawą. Obie kategorie znaków pełnią te same funkcje — oznaczenie pochodzenia, jakościową i reklamową. Różni je jedynie źródło ochrony, które w wypadku znaków zarejestrowanych wynika $\mathrm{z}$ udzielonego prawa ochronnego, w wypadku zaś niezarejestrowanych swoją podstawę znajduje $\mathrm{w}$ fakcie rzeczywistego posługiwania się oznaczeniem, a nie wydanej decyzji ${ }^{8}$. Kwestia istnienia prawa podmiotowego do niezarejestrowanego znaku towarowego zostanie omówiona w dalszej części artykułu.

\section{Niezarejestrowane znaki towarowe jako oznaczenie towarów i usług na gruncie ustawy o zwalczaniu nieuczciwej konkurencji}

Ochrona znaków towarowych, oprócz dbałości o niewprowadzanie w błąd konsumentów, ma obejmować też zagrożone lub naruszane interesy przedsiębiorcy 9 . Ochrona znaków towarowych powstała w celu zapewnienia uczciwej konkurencji między przedsiębiorcami ${ }^{10}$, aby konsument mógł dokonać optymalnego wyboru. Aktualnie do ochrony niezarejestrowanych znaków towarowych najczęściej wykorzystuje się przepisy ustawy o zwalczaniu nieuczciwej konkurencji, w szcze-

${ }^{6}$ I. Nestoruk, M. Kępiński, J. Kępiński, Oznaczenia odróżniające, [w:] System Prawa Prywatnego, t. 15. Prawo konkurencji, red. M. Kępiński, Warszawa 2013, s. 200.

${ }^{7}$ M. Kondrat, op. cit., rozdz. 1.

8 I. Nestoruk, M. Kępiński, J. Kępiński, op. cit., s. 200.

9 E. Nowińska, [w:] E. Nowińska, K. Szczepanowska-Kozłowska, Ustawa o zwalczaniu nieuczciwej konkurencji. Komentarz, Warszawa 2017, LEX 10686, art. 10.

10 M. Kondrat, op. cit., rozdz. 1. 
gólności art. 10 ustawy ${ }^{11}$, zgodnie z którym „Czynem nieuczciwej konkurencji jest takie oznaczenie towarów lub usług albo jego brak, które może wprowadzić klientów w błąd co do pochodzenia, ilości, jakości, składników, sposobu wykonania, przydatności, możliwości zastosowania, naprawy, konserwacji lub innych istotnych cech towarów albo usług, a także zatajenie ryzyka, jakie wiąże się z korzystaniem z nich". $Z$ treści tego przepisu można, w sposób pośredni, wyprowadzić podstawę ochrony znaków towarowych, którym nie przysługuje ochrona wynikająca z przepisów Prawa własności przemysłowej, jeżeli czyn nieuczciwej konkurencji polega na oznaczaniu towarów nieprzysługującym naruszycielowi znakiem. Możliwe jest to w drodze wykładni przy toczonego przepisu, który choć nie mówi o znakach towarowych, wprost posługuje się terminem „oznaczenie towarów". Taką zaś funkcję pełnią wszystkie znaki towarowe jako odznaczenia indywidualizujące, niezależnie od ich formalnoprawnego statusu. Pod pojęciem tym można rozumieć wszelkie znaki towarowe, które są rzeczywiście używane w obrocie. W ten sposób przepis art. 10 ustawy o zwalczaniu nieuczciwej konkurencji uzupełnia ochronę oznaczeń przedsiębiorców przewidzianą w Prawie własności przemysłowej, rozciągając ją też na znaki, które nie uzyskały ochrony w wyniku decyzji administracyjnej ${ }^{12}$.

Odnośnie do ochrony na podstawie przepisów ustawy o zwalczaniu nieuczciwej konkurencji rysuje się problem charakteru prawnego uprawnień przyznawanych przez przepisy wskazanej ustawy. Można wyróżnić dwa stanowiska. Jedno z nich zakłada, że ustawy o zwalczaniu nieuczciwej konkurencji pozwalają jedynie na ochronę swoich praw w drodze odpowiedzialności deliktowej sprawcy naruszenia. Takie stanowisko zajmuje także część przedstawicieli doktryny oraz orzecznictwo, przychylając się do udzielenia ochrony w oparciu o konstrukcje deliktu. Pogląd ten wzmacnia fakt, że w przypadku znaków towarowych zarejestrowanych ustawodawca $\mathrm{w}$ ustawie Prawo własności przemysłowej nie posługuje się pojęciem prawa do znaku towarowego, zastępując go pojęciem ,prawo ochronne na znak towarowy". Tworzy to tak zwaną wąską wykładnię pojęcia prawa do znaku towarowego utożsamiającą ją z prawem ochronnym na znak towarowy ${ }^{13}$. Również jedynie pod warunkiem zgłoszenia do rejestracji prawo do takiego znaku uważane byłoby za składnik przedsiębiorstwa w rozumieniu art. $55^{1}$ kodeksu cywilnego ${ }^{14}$ (takie jest stanowisko części doktryny, nawet mimo otwartego charakteru katalogu $\mathrm{z}$ art. $55^{1}$ kodeksu cywilnego) ${ }^{15}$.

11 I. Nestoruk, M. Kępiński, J. Kępiński, op. cit., s. 209.

12 A. Michalak, [w:] Ustawa o zwalczaniu nieuczciwej konkurencji. Komentarz, red. M. Sieradzka, M. Zdyb, Warszawa 2016, LEX 10315, art. 10 pkt 8.

13 M. Trzebiatowski, Prawo do niezarejestrowanego znaku towarowego jako składnik przedsiębiorstwa, ,Rejent” 2009, nr 5, s. 101.

14 Ustawa z dnia 23 kwietnia 1964 roku — Kodeks cywilny, Dz.U. z 1964 r. Nr 16, poz. 93.

15 Ibidem. 
Drugi z poglądów wyraża stanowisko, że ustawy o zwalczaniu nieuczciwej konkurencji kształtuje bezwzględne prawo podmiotowe uprawnionego do oznaczenia. Oznacza to, że uprawniony mógłby zakazać używania niezarejestrowanego oznaczenia ze względu na ścisłe prawo do dysponowania oznaczeniem, skuteczne erga omnes. Stanowisko takie przeważa w systemie prawa amerykańskiego, przewidującym powstanie odrębnego prawa do znaku w wyniku jego używania $^{16}$. Konstrukcja prawa podmiotowego do oznaczenia wydaje się też lepiej przystawać do współczesnego obrotu prawnego, w którym znaki towarowe zaczęły odgrywać coraz większą rolę. Zgodnie z tak zwaną teorią kompromisową praw podmiotowych , prawo podmiotowe to moc woli przyznana jednostce przez porządek prawny jako środek do zaspokojenia ludzkich interesów"17. Obecnie widać tendencję do podzielania tego poglądu przez coraz szersze kręgi naukowe. Wiąże się to $\mathrm{z}$ uznaniem tak zwanego mieszanego sposobu istnienia prawa ochronnego na znak towarowy, który oprócz rejestracji wymaga używania tego znaku w obrocie, nawet jeśli nie uzyska on powszechnej znajomości ${ }^{18}$. Dodatkowym argumentem wzmacniającym tezę o prawie podmiotowym ukształtowanym na podstawie art. 10 ustawy o zwalczaniu nieuczciwej konkurencji jest istnienie prawa używacza uprzedniego na podstawie art. 160 Prawa własności przemysłowej. Podobny charakter obu omawianych instytucji pozwala na sformułowanie wniosków wspierających tezę o istnieniu odrębnego prawa podmiotowego.

Niezależnie od przyjętego stanowiska ochrona przysługuje dysponentom znaku na podstawie wskazanych przepisów. Taki rodzaj ochrony wybierany jest najczęściej z kilku powodów. Pierwszym z nich jest sytuacja, gdy oznaczenie nie jest rejestrowane z powodu braku woli uprawnionego, występowania przeszkód w rejestracji lub posługiwania się przez uprawnionego grupą różnych odmian znaku, które nie zawsze mogą uzyskać ochronę przez podobieństwo do znaku podstawowego ${ }^{19}$. Jednocześnie oznaczenie takie jest używane w obrocie. Jednak ochrona takiego znaku, jest uzależniana od tego, czy konsumenci uznają dany symbol za wyróżniający towar na rynku oraz czy uznają go za przypisany do konkretnego przedsiębiorcy ${ }^{20}$.

Druga z sytuacji występuje, gdy przedsiębiorca co prawda zgłosił znak do rejestracji, jednak nie zostało jeszcze wydane rozstrzygnięcie co do przyznania prawa ochronnego. W czasie gdy uprawniony oczekuje na wydanie decyzji o udzieleniu prawa ochronnego, nie przysługuje mu żadna ochrona na podstawie przepisów Prawa własności przemysłowej ${ }^{21}$ (z wyjątkiem znaków powszechnie znanych oraz

16 A. Michalak, op. cit., art. 10 pkt 12.

17 M. Pyziak-Szafnicka, Prawo podmiotowe, [w:] System Prawa Prywatnego, t. 1. Prawo cywilne-część ogólna, red. M. Safjan, Warszawa 2012, s. 783.

18 M. Trzebiatowski, op. cit., s. 103.

19 I. Nestoruk, M. Kępiński, J. Kępiński, op. cit., s. 202.

${ }^{20}$ Ibidem.

21 A. Michalak, op. cit., art. 10 pkt 8. 
renomowanych). Nie należy to do rzadkości, zważywszy, że średni czas oczekiwania na rozstrzygnięcie w Urzędzie Patentowym RP wynosi trzy lata.

Aktualizacja ochrony znaku na podstawie przepisów ustawy o zwalczaniu nieuczciwej konkurencji może nastąpić, gdy identycznym znakiem (lub łudząco podobnym) posługują się przynajmniej dwa podmioty jednocześnie, a jeden z nich musiał zacząć używać spornego oznaczenia wcześniej. Przepis sankcjonuje wprowadzenie konsumentów w błąd, uniemożliwiając im dokonanie efektywnego wyboru, co w wypadku znaków towarowych ma znaczenie przy wprowadzeniu w błąd co do pochodzenia towaru. By domagać się ochrony na podstawie przytoczonego przepisu, wystarczy zaistnienie ryzyka wystąpienia pomyłki. Nie jest konieczne zaistnienie realnej pomyłki konsumenta. Do powstania ochrony konieczne jest wykazanie rzeczywistego używania znaku, jednak nie musi być ono ciągłe i nieprzerwane ${ }^{22}$. Istotne jest jedynie pierwszeństwo posługiwania się oznaczeniem. Ochronę z ustawy o zwalczaniu nieuczciwej konkurencji uzyska to przedsiębiorstwo, które wcześniej rozpoczęło używanie, czyli chronologicznie pojawiło się w obrocie jako pierwsze. Odnośnie do możliwych sprawców czynu nieuczciwej konkurencji art. 10 zawęził ich grono jedynie do przedsiębiorców ${ }^{23}$.

W przeciwieństwie do uprawnień wynikających z prawa ochronnego na zarejestrowany znak towarowy przepisy ustawy o zwalczaniu nieuczciwej konkurencji, zgodnie ze stanowiskiem znacznej części doktryny, nie dają uprawnienia do wykluczenia innych osób z możliwości wykorzystywania znaku. Stanowią one jedynie podstawę do dochodzenia naprawy szkody oraz zaprzestania naruszeń ze strony innych przedsiębiorców. Wymaga to udowodnienia zaistnienia naruszenia w rozumieniu art. 3 ustawy. Naruszenie przepisu powstaje nie tylko w wyniku fizycznego oznaczenia towaru nienależnym znakiem towarowym, lecz także przez posługiwanie się nim w obrocie w inny sposób, na przykład stosowanie go w reklamie ${ }^{24}$. Taki sposób działania prowadzi do wprowadzenia w błąd przeciętnego klienta co do rzeczywistego pochodzenia towaru. Jak wskazano na wstępie, ochrona na podstawie art. 10 ustawy o zwalczaniu nieuczciwej konkurencji ma chronić przed taką pomyłką. Ustalenie, czy w wypadku korzystania przez przedsiębiorców z podobnych lub identycznych niezarejestrowanych znaków towarowych powoduje ryzyko takiej pomyłki, wymaga oceny występujących w sprawie okoliczności faktycznych. W wypadku, w którym wcześniejsze oznaczenie byłoby szerzej rozpowszechnione na rynku, ryzyko to rośnie.

Ważne będzie też udowodnienie rzeczywistego stosowania w obrocie gospodarczym. Nie wystarczy jednak wskazanie przynależności znaku do konkretnego przedsiębiorstwa, ale konieczne będzie udowodnienie jego używania do oznaczenia towarów oraz w kontaktach z kontrahentami.

22 E. Nowińska, op. cit., art. 10.

23 A. Michalak, op. cit., art. 10 pkt 13.

24 Ibidem, art. 10 pkt 14. 
Uprawnienia, jakie przysługują osobie używającej znaku towarowego chronionego na podstawie art. 10 ustawy o zwalczaniu nieuczciwej konkurencji, obejmują:

1. zaniechania niedozwolonych działań;

2. usunięcia skutków niedozwolonych działań;

3. złożenia jednokrotnego lub wielokrotnego oświadczenia odpowiedniej treści i w odpowiedniej formie;

4. naprawienia wyrządzonej szkody, na zasadach ogólnych;

5. wydania bezpodstawnie uzyskanych korzyści, na zasadach ogólnych;

6. zasądzenia odpowiedniej sumy pieniężnej na określony cel społeczny związany ze wspieraniem kultury polskiej lub ochroną dziedzictwa narodowego jeżeli czyn nieuczciwej konkurencji był zawiniony.

Kończąc omówienie możliwości ochrony na podstawie art. 10 ustawy o zwalczaniu nieuczciwej konkurencji, należy wskazać, że ochrona na podstawie przepisów o zwalczaniu nieuczciwej konkurencji opiera się głównie na przesłance rzeczywistego posługiwania się oznaczeniem w obrocie, co odróżnia ją od przesłanek, jakie należy spełnić w celu ochrony przewidzianej w Prawie własności przemysłowej. $Z$ tego też powodu przepisy obydwóch reżimów nie są z sobą w pełni uzgodnione. Możliwe są zatem kolizje między obydwoma systemami ochrony prawnej. Najpopularniejszym przypadkiem występującej kolizji jest konflikt między znakiem faktycznie używanym a znakami towarowymi i usługowymi zarejestrowanymi na podstawie przepisów Prawa własności przemysłowej. Może to doprowadzić nie tylko do możliwości zakazania posługiwania się później używanym znakiem, na który udzielono prawa ochronnego, lecz także stanowić przeszkodę w rejestracji tak zgłoszonego znaku, ze względu na naruszanie interesów przedsiębiorcy-użytkownika niezarejestrowanego znaku. Dzieje się tak, ponieważ większościowy pogląd w polskim systemie prawnym zakłada pierwszeństwo uprawnień wynikających z ustawy o zwalczaniu nieuczciwej konkurencji przed uprawnieniami wynikającymi z rejestracji ${ }^{25}$ ze względu na ich formalny charakter, który musi ustąpić przed materialną podstawą ochrony wynikającą z używania $^{26}$. Uprawnienia do korzystania z niezarejestrowanego znaku mają charakter majątkowy ${ }^{27}$. Dlatego stanowić będą one składnik przedsiębiorstwa na równi ze znakami zarejestrowanymi ${ }^{28}$. Mogą więc jako takie być przedmiotem umowy licencyjnej i umowy o przeniesieniu znaku na innego przedsiębiorcę. Jako element przedsiębiorstwa podlega zbyciu zarówno wraz z całym przedsiębiorstwem, jak i w ramach jego części ${ }^{29}$.

25 M. Kępiński, J. Kępiński, I. Wiszniowska, [w:] Ustawa o zwalczaniu nieuczciwej konkurencji, komentarz, red. J. Szwaja, Warszawa 2013 s. 318.

26 Ibidem.

27 M. Trzebiatowski, [w:] System Prawa Prywatnego, t. 14B. Prawo własności przemystowej, red. R. Skubisz, Warszawa 2017, s. 857.

28 Ibidem, s. 858.

29 I. Nestoruk, M. Kępiński, J. Kępiński, op. cit., s. 215. 


\section{Niezarejestrowany znak towarowy jako firma przedsiębiorcy bądź oznaczenie przedsiębiorstwa}

Oprócz używania niezarejestrowanych znaków do oznaczania towarów wielu przedsiębiorców w praktyce utożsamia symbole służące do oznaczania produktów z oznaczeniem całego przedsiębiorstwa (koncern Fiat, Spółdzielnia „Polityka” itp. ${ }^{30}$. W wypadku stosowania tak zwanego znaku firmowego, który oznacza znak towarowy identyczny z oznaczeniem przedsiębiorstwa lub przedsiębiorcy, otwiera się pole do dochodzenia ochrony niezarejestrowanego znaku towarowego nie tylko jako wprowadzającego w błąd oznaczenia towaru, lecz także jako naruszenia firmy oraz oznaczenia przedsiębiorstwa. Nie oznacza to jednak, że występowanie znaku firmowego jest koniecznym warunkiem do dochodzenia roszczeń $\mathrm{z}$ art. 5 ustawy o zwalczaniu nieuczciwej konkurencji w wypadku jego użycia w charakterze znaku towarowego przez konkurentów. W wypadku wystarczającej rozpoznawalności oznaczenia uprawniony nabywa możliwość zakazania wykorzystywania swojego symbolu, nawet jeżeli nie korzysta z niego bezpośrednio w charakterze znaku towarowego ${ }^{31}$. Już samo nałożenie (zgodnie z ukształtowaną linią orzeczniczą) cudzego oznaczenia przedsiębiorstwa na towary innego przedsiębiorcy oznacza wprowadzenie w błąd co do pochodzenia towarów ${ }^{32}$.

Dzieje się tak mimo odrębności między znakiem towarowym a oznaczeniem przedsiębiorstwa. Należy podkreślić, że główną funkcją oznaczenia przedsiębiorstwa jest jego indywidualizacja jako występującego w obrocie gospodarczym, a nie wskazywanie pochodzenia jego produktów i usług. Tymczasem znak towarowy w każdej postaci służy do komunikacji konsumentowi o komercyjnym pochodzeniu towaru. Dlatego pełnienie przez jedno oznaczenie lub symbol obu funkcji w praktyce jest wyjątkowe, dochodzenie zaś ochrony swoich uprawnień do znaku na podstawie art. 5 ustawy o zwalczaniu nieuczciwej konkurencji jest możliwe wyłącznie, gdy używany znak pozwala na wystarczające skojarzenie go z konkretnym przedsiębiorstwem jako całym podmiotem. Zachodzi to w wypadku używania go do promowania działań przedsiębiorstwa, przez co następuje skojarzenie w powszechnej świadomości między używanymi symbolami i znakami a konkretnym przedsiębiorstwem. Należy przez to podejmować określone działania wiążące się z doprowadzeniem do rozpoznawania znaku przez konsumentów ${ }^{33}$. W takim wypadku uprawniony do oznaczenia przedsiębiorstwa otrzymuje wyłączne uprawnienie do wykorzystywania charakterystycznych elementów, przez co może zakazać używania elementów swojego oznaczenia w ramach znaków towarowych innego przedsiębiorcy.

30 Ibidem, s. 211.

31 M. Kępiński, J. Kępiński, I. Wiszniowska, op. cit., s. 323.

32 Ibidem, s. 324.

33 Wyrok Sądu Najwyższego z dnia 17 lutego 2005 roku, I CK 626/04, OSP 2005/12/148, LEX nr 160529. 
Drugą możliwość ochrony znaków firmowych zawierają przepisy prawa firmowego, zgodnie z którymi chroniona jest firma przedsiębiorcy prowadząca działalność gospodarczą. Firma wyróżnia podmiot działający w obszarze obrotu gospodarczego, a nie samo przedsiębiorstwo jako oznaczenie przedsiębiorstwa z ustawy o zwalczaniu nieuczciwej konkurencji, w ten sposób nie stanowi części przedsiębiorstwa w rozumieniu kodeksu cywilnego ${ }^{34}$. W wypadku firmy nie ma wątpliwości co do jej charakteru prawnego. Ma ona charakter prawa podmiotowego bezwzględnie skutecznego erga omnes, przysługującego przedsiębiorcy. Ma charakter majątkowy, mimo że nie można jej zbyćc ${ }^{35}$. Indywidualizuje ona przedsiębiorcę, pełni funkcję reklamową oraz służy do odróżniania jednego przedsiębiorcy od pozostałych uczestników obrotu. Używana w charakterze nazwy handlowej pozwala na identyfikację towarów i usług pochodzących od uprawnionego przedsiębiorcy.

Pełniąc też funkcję reklamową, umacnia skojarzenie użytych w niej nazw i symboli z dysponentem prawa do firmy oraz w konsekwencji wzmacnia więź między przedsiębiorcą a zakresem działalności i towarami, które zostały nią opatrzone. Ma to szczególne znaczenie, gdy w celach reklamowych uprawniony posługuje się zarówno firmą, jak i znakiem towarowym, w którym zawarte są elementy jego firmy ${ }^{36}$. Zgodnie z art. $43^{3} \S 2$ kodeksu cywilnego firma nie może wprowadzać w błąd w szczególności co do osoby przedsiębiorcy, przedmiotu prowadzonej działalności, jej miejsca i źródeł zaopatrzenia. Nie jest to jednak katalog zamknięty. Uprawniony do wcześniejszej firmy ma prawo do jej ochrony przed utratą zdolności odróżniającej w obrocie w wyniku rozpowszechniania się późniejszego znaku towarowego konkurenta.

Prowadząc jednak porównanie firmy oraz znaków towarowych, należy pamiętać, że na gruncie prawa polskiego występują różne rodzaje znaków - znak towarowy może przyjmować różne formy, także dźwiękowe lub zapachowe. Firma $\mathrm{z}$ kolei musi odpowiadać wymogom narzuconym przez prawo w zakresie jej konstrukcji ${ }^{37}$.

W wypadku naruszenia prawa do firmy zgodnie $\mathrm{z}$ art $43^{10}$ kodeksu cywilnego: „Przedsiębiorca, którego prawo do firmy zostało zagrożone cudzym działaniem, może żądać zaniechania tego działania, chyba że nie jest ono bezprawne. W razie dokonanego naruszenia może on także żądać usunięcia jego skutków, złożenia oświadczenia lub oświadczeń w odpowiedniej treści i formie, naprawienia na zasadach ogólnych szkody majątkowej lub wydania korzyści uzyskanej przez osobę, która dopuściła się naruszenia".

34 M. Pazdan, Dobra osobiste i ich ochrona, [w:] System Prawa Prywatnego, t. 1, s. 1244.

35 I. Nestoruk, M. Kępiński, J. Kępiński, op. cit., s. 186.

36 J. Sitko, Firma i jej ochrona, Warszawa 2009, LEX 98109, rozdz. 2.4.

37 I. Nestoruk, M. Kępiński, J. Kępiński, op. cit., s. 184. 


\section{Pozostałe możliwości uzyskania ochrony na niezarejestrowany znak towarowy}

Mimo nieuregulowania wprost znaków niezarejestrowanych w przepisach Prawa własności przemysłowej, w ustawie znajdują się instytucje, którymi można posłużyć się w celu znalezienia ochrony dla symboli pozbawionych rejestracji. Mowa tu o znakach renomowanych oraz znakach powszechnie znanych.

Podobnie jak niezarejestrowane znaki towarowe, znak towarowy renomowany również nie ma legalnej definicji. Najczęściej doktryna przyjmuje, że znak taki nabywa charakteru renomowanego, gdy jest znany dużej grupie odbiorców oraz ma siłę przyciągania wynikającą z dobrej opinii klientów ${ }^{38}$. Nawet jednak osiągnięcie takiej pozycji przez znak niezarejestrowany nie będzie przeszkodą w rejestracji znaku podobnego. Znak renomowany może być podstawą odmowy rejestracji, ale tylko gdy został zarejestrowany lub zgłoszony do rejestracji z wcześniejszym pierwszeństwem. W przeciwnym wypadku będzie chroniony jedynie jak niezarejestrowany znak towarowy zwykły.

Inaczej będzie w odniesieniu do znaku towarowego notoryjnego (powszechnie znanego). Zgodnie z art. 16 ust. 2 zd. 2 TRIPS, ,przy określaniu, czy znak towarowy jest powszechnie znany, Członkowie wezmą pod uwagę znajomość tego znaku towarowego w odpowiednim kręgu odbiorców, włączając jego znajomość na terytorium zainteresowanego Członka będącą wynikiem promocji tego znaku towarowego". Jak widać, za znak powszechnie znany może uchodzić oznaczenie znane szerokiemu gronu potencjalnych konsumentów. Często spotyka się wymóg, by było to ponad $50 \%$ potencjalnych członków grupy, wydaje się on jednak zbyt wysoki. Zgodnie z art. $132^{1} \S 1$ pkt 5 Prawa własności przemysłowej nie udziela się prawa ochronnego na znak ,identyczny lub podobny do znaku towarowego, który przed datą, według której oznacza się pierwszeństwo do uzyskania prawa ochronnego, był w Rzeczypospolitej Polskiej powszechnie znany i używany jako znak towarowy przeznaczony do oznaczania towarów identycznych lub podobnych pochodzących od innej osoby, jeżeli zachodzi ryzyko wprowadzenia odbiorców w błąd, które obejmuje w szczególności ryzyko skojarzenia znaku zgłoszonego ze znakiem powszechnie znanym". Uzyskanie przez znak towarowy statusu powszechnie znanego będzie więc względną przeszkodą przy rejestracji podobnego znaku towarowego.

Z innych praw do oznaczenia, z których może skorzystać jego użytkownik, należy wymienić ukształtowane przez prawo cywilne dobra osobiste oraz ochronę prawnoautorską.

Ochronę prawa autorskiego mogą uzyskać znaki towarowe, które charakteryzują się cechami utworu, niezależnie od rejestracji w Urzędzie Patentowym.

38 E. Wojcieszko-Głuszko, Pojęcie znaku towarowego. Rodzaje oznaczeń. Kategorie znaków towarowych, [w:] System Prawa Prywatnego, t. 14B, s. 548. 
Stanowisko to zajął Sąd Najwyższy, który w wyroku z dnia 23 czerwca 1989 roku stwierdził, że niezarejestrowany znak towarowy korzysta z ochrony prawa autorskiego, jeżeli odpowiada wymaganiom stawianym dziełom sztuki ${ }^{39}$. Takie samo stanowisko zajął w wyroku z 22 czerwca 2010 roku $^{40}$. Oznacza to, że do ochrony prawnoautorskiej znak towarowy musi odznaczać się indywidualnymi elementami o charakterze twórczym ${ }^{41}$. O stopniu twórczości danego znaku należy orzekać według okoliczności konkretnej sprawy. Ochronę prawnoautorską znaku potwierdza także praktyka Urzędu Patentowego, który niejednokrotnie odmawiał rejestracji znaku z powodu naruszenia praw autorskich ${ }^{42}$.

Uprawniony do znaku może w dochodzeniu swoich praw skorzystać z ogólnej konstrukcji dobra osobistego. Katalog dóbr osobistych ma charakter otwarty. $\mathrm{Na}$ podstawie art. 23 i 24 kodeksu cywilnego ochrona cywilna przysługuje nazwie osoby prawnej oraz firmie przedsiębiorcy ${ }^{43}$, co jest dodatkowym wzmocnieniem ochrony firmy przewidzianym $\mathrm{w}$ art. $43^{1}$ i następnych kodeksu cywilnego (tak na przykład M. Pazdan). Obydwa oznaczenia służą indywidualizacji uprawnionego podmiotu, $\mathrm{z}$ tego też powodu dysponenci dobra osobistego w postaci oznaczenia mogą wystąpić wobec osób trzecich o zakaz korzystania z oznaczeń, jeśli mogłoby to doprowadzić do omyłki ${ }^{44}$. Podobnie odnosi się to do innych oznaczeń indywidualizujących przedsiębiorstwo na przykład w postaci znaków ${ }^{45}$, jeśli tylko pełnią funkcje identyfikacyjne. Dodatkowo na podstawie przepisu art. 23 kodeksu cywilnego chroniona jest też działalność twórcza i artystyczna. Pozwala to na zastosowanie ochrony z tytułu dobra osobistego w wypadku, gdy znak towarowy przedstawiałby takie cechy ${ }^{46}$.

\section{Wnioski i podsumowanie}

Nierejestrowane znaki towarowe stanowią wciąż niedookreśloną prawnie materię własności intelektualnej. Ich występowanie w obrocie gospodarczym oraz wyraźne odróżnienie od znaku, na które udzielone zostało prawo ochronne, nie budzi wątpliwości. Brak odrębnej regulacji obejmującej niezarejestrowane znaki towarowe w Prawie własności przemysłowej powoduje konieczność poszukiwania ochrony z wykorzystaniem instytucji, które tylko w wyniku odpowiedniej

39 J. Barta et al., Przedmiot prawa autorskiego, [w:] System Prawa Prywatnego, t. 13. Prawo autorskie, red. J. Barta, Warszawa 2013, s. 49.

40 Ibidem.

41 J. Kępiński, Czy znak towarowy może być utworem, ,Ruch Prawniczy, Ekonomiczny i Socjologiczny" 2015, nr 2, s. 182.

42 J. Barta et al., op. cit., s. 49.

43 M. Pazdan, op. cit., t. 1, s. 1243-1245.

44 Ibidem, s. 1243.

45 Ibidem.

46 Ibidem, s. 1258. 
interpretacji pozwalają na dochodzenie swoich uprawnień przez korzystających z tego rodzaju znaków. Za konieczne należy uznać wprowadzenie ustawowego rozstrzygnięcia $\mathrm{w}$ zakresie istnienia prawa podmiotowego do znaku niezarejestrowanego. Wcześniejsze poglądy odmawiające niezarejestrowanym znakom towarowym charakteru dobra osobistego podmiotów gospodarczych oraz wykluczające je z części składowych przedsiębiorstwa nie odpowiadają już wymogom współczesnego rynku, który w wyniku rozwoju marketingu oraz świadomości konsumenckiej uczynił z oznaczeń używanych w obrocie jeden z głównych elementów działalności biznesowej. W doktrynie polskiej prawo podmiotowe to zbiór powiązanych wzajemnie uprawnień, przyznanych i zabezpieczonych normą prawną. Uzupełniający charakter przepisów ustawy o zwalczaniu nieuczciwej konkurencji nie wyklucza uznania za prawo podmiotowe uprawnień przyznanych na podstawie przepisów o zwalczaniu nieuczciwej konkurencji. Jest tak dlatego, że przepisy o zwalczaniu nieuczciwej konkurencji zapewniają ochronę $\mathrm{w}$ takim zakresie, w jakim nie czynią tego przepisy własności przemysłowej ani prawa autorskiego $^{47}$. Co więcej uprawnienia, jakie przysługują dysponentom obu kategorii znaków na podstawie Prawa własności przemysłowej oraz ustawy o zwalczaniu nieuczciwej konkurencji są zbliżone ${ }^{48}$. Prawa do oznaczenia towarów oraz do oznaczenia przedsiębiorstwa są wystarczająco skonkretyzowane, by wywieść z nich uprawnienia przedsiębiorcy i zapewnić wyłączność na korzystanie z oznaczeń. Rozwiązaniem istniejących wątpliwości byłoby wprowadzenie przez ustawodawcę odrębnego przepisu odnoszącego się do znaków towarowych na gruncie Prawa własności przemysłowej lub Prawa zwalczania nieuczciwej konkurencji.

Obecnie z powodu dyskusji oraz rozbieżnych stanowisk należy uznać, że ochrona niezarejestrowanych znaków jest dalece niewystarczająca. Nieprzesądzenie o własnościowym charakterze nierejestrowanego znaku towarowego uniemożliwia poprawne realizowanie celów wyznaczonych wszystkim znakom towarowym — informowaniu o komercyjnym pochodzeniu towarów od konkretnego przedsiębiorcy. Konieczność posługiwania się przepisami udzielającymi ochrony pośredniej oraz stosowanie analogii wprowadza niepewność w zakresie obrotu prawnego oraz prowadzenia działalności gospodarczej. Powinno to zostać rozwiązane przez wprowadzenie odrębnego przepisu przyznającego wprost nierejestrowanym znakom towarowym charakter elementu przedsiębiorstwa występującego $\mathrm{w}$ obrocie i chronionego przepisami rangi ustawowej, oprócz już funkcjonującego w art. $55^{1}$ kodeksu cywilnego pojęcia oznaczenia indywidualizującego przedsiębiorstwo oraz praw własności przemysłowej. Byłoby to także zgodne $\mathrm{z}$ aktualnymi tendencjami prawa unijnego, które charakteryzuje prawa do znaku niezarejestrowanego jako własność.

47 M. Trzebiatowski, Prawo do niezarejestrowanego znaku towarowego jako składnik przedsiębiorstwa, s. 106.

48 Ibidem, s. 104. 


\section{Bibliografia}

Barta J. et al., Przedmiot prawa autorskiego, [w:] System Prawa Prywatnego, t. 13. Prawo autorskie, red. J. Barta, Warszawa 2013.

Kępiński J., Czy znak towarowy może być utworem, „Ruch Prawniczy, Ekonomiczny i Socjologiczny" 2015, nr 2.

Kępiński M., [w:] Ustawa o zwalczaniu nieuczciwej konkurencji, komentarz, red. J. Szwaja, Warszawa 2013.

Kondrat M., Ochrona znaków towarowych przed naruszeniami w internecie, Warszawa 2008, LEX 81492.

Michalak A., [w:] Ustawa o zwalczaniu nieuczciwej konkurencji. Komentarz, red. M. Sieradzka, M. Zdyb, Warszawa 2016, LEX 10315.

Nestoruk I., Kępiński M., Kępiński J., Oznaczenia odróżniające, [w:] System Prawa Prywatnego, t. 15. Prawo konkurencji, red. M. Kępiński, Warszawa 2013.

Nowińska E., Szczepanowska-Kozłowska K., Ustawa o zwalczaniu nieuczciwej konkurencji. Komentarz, Warszawa 2017, LEX 10686.

Pazdan M., Dobra osobiste i ich ochrona, [w:] System Prawa Prywatnego, t. 1. Prawo cywilne część ogólna, red. M. Safjan, Warszawa 2012.

Pyziak-Szafnicka M., Prawo podmiotowe, [w:] System Prawa Prywatnego, t. 1. Prawo cywilne część ogólna, red. M. Safjan, Warszawa 2012.

Sitko J., Firma i jej ochrona, Warszawa 2009, LEX 98109.

Trzebiatowski M., [w:] System Prawa Prywatnego, t. 14B. Prawo własności przemysłowej, red. R. Skubisz, Warszawa 2017.

Trzebiatowski M., Prawo do niezarejestrowanego znaku towarowego jako składnik przedsiębiorstwa, „Rejent” 2009, nr 5.

Ustawa o zwalczaniu nieuczciwej konkurencji, komentarz, red. J. Szwaja, Warszawa 2013.

Wojcieszko-Głuszko E., Pojęcie znaku towarowego. Rodzaje oznaczeń. Kategorie znaków towarowych, [w:] System Prawa Prywatnego, t. 14B. Prawo własności przemysłowej, red. R. Skubisz, Warszawa 2017.

\section{Akty prawne}

Rozporządzenie Parlamentu Europejskiego i Rady (UE) 2017/1001 z dnia 14 czerwca 2017 roku w sprawie znaku towarowego Unii Europejskiej, Dz.U.UE.L.2017.154.1.

Ustawa z dnia 23 kwietnia 1964 roku — Kodeks cywilny, Dz.U. z 1964 r. Nr 16, poz. 93.

Ustawa z dnia 16 kwietnia 1993 roku o zwalczaniu nieuczciwej konkurencji, Dz.U. z 1993 r. Nr 47, poz. 211.

Ustawa z dnia 4 lutego 1994 roku o prawie autorskim i prawach pokrewnych, Dz.U. z 1994 r. Nr 24, poz. 83.

Ustawa z dnia 30 czerwca 2000 roku Prawo własności przemysłowej, Dz.U. z 2001 r. Nr 49, poz. 508.

\section{Orzecznictwo}

Wyrok Sądu Najwyższego z dnia 23 czerwca 1989 roku, I CR 236/89, PS 1992/2/106, LEX nr 8976. Wyrok Sądu Najwyższego z dnia 17 lutego 2005 roku, I CK 626/04, OSP 2005/12/148, LEX nr 160529.

Wyrok Sądu Najwyższego z dnia 22 czerwca 2010 roku, IV CSK 359/09, OSNC 2011/2/16, LEX nr 694269. 


\title{
Without trademark registration - on how to protect unregistered trademarks from violations under Polish law
}

\author{
Summary
}

Unregistered trademarks are still an undefined intellectual property matter. There is no doubt about their existence in the course of trade and a clear distinction from the sign on which the protection right was granted. The lack of a separate regulation covering unregistered trademarks in industrial property law makes it necessary to search for protection using institutions that only as a result of an appropriate interpretation allow for the exercise of their rights by those who use such marks. A decision regarding the existence of a subjective right to an unregistered sign should be considered necessary. Previous views refusing unregistered trademarks the character of the personal good of business entities and excluding them from the company's components no longer meet the requirements of the modern market, which as a result of the development of marketing and consumer awareness has made signs used in the market one of the main elements of business. In the Polish doctrine, the subjective right is a set of related powers, granted and protected by a legal norm. The complementary nature of the provisions of the Act on Combating Unfair Competition does not preclude recognition of the rights granted by them as a subjective right. This is due to the fact that the provisions on combating unfair competition provide protection to the extent that it is not done by industrial property legislation or copyright law. What is more, the rights vested in the holders of both categories of marks based on Industrial Property Law and the Act on Combating Unfair Competition are similar. The rights to mark the goods and to mark the company are sufficiently specific to derive the entrepreneur's rights from them and ensure exclusivity for the use of signs. The solution to the existing doubts would be the introduction by the legislator of a separate provision relating to trademarks on the basis of industrial property law or the law against unfair competition.

At the moment, due to discussions and divergent positions, it should be recognized that the protection of unregistered marks is far from sufficient. The lack of a decree about the proprietary character of an unregistered trademark makes it impossible to correctly meet the goals set for all trademarks, i.e. informing about commercial origin of goods from a specific entrepreneur. The necessity to use regulations granting indirect protection and the fact of applying analogy introduces uncertainty in the scope of legal transactions and conducting business activity, which should be solved by introducing a separate provision granting unregistered trademarks of a trade mark which is a component of an undertaking and protected by statutory provisions, next to the already functioning in Article $55^{1}$ of the Civil Code, the notion of the individualization designation of enterprises and industrial property rights. It would also be in line with current EU law trends that characterize the rights to the unregistered mark as a property. 